\title{
The politics of the polyphony of performance
}

\section{Musicalization in contemporary German theatre1}

David Roesner

\section{Introduction}

Eine gute Inszenierung ist wie ein guter Song. ${ }^{2}$ (Michael Thalheimer)

Over the past fifteen years contemporary German theatre has seen what could well be described as a 'musical turn' - though the notion of paradigmatic shifts expressed in phrases like 'linguistic turn', 'pictorial turn' and 'performative turn' has created a certain surfeit of such terms. The discovery and re-discovery of the musicality of the theatrical process and event, which we can see and study when looking at productions by Heiner Goebbels, Christoph Marthaler, Ruedi Häusermann, Stefan Pucher, René Pollesch, Manos Tsangaris, Einar Schleef, Sebastian Nübling, Michael Thalheimer, Theater der Klänge, Lose Combo and others, is not an entirely new phenomenon. Rather, I argue, that recently it has been attracting more critical and academic attention and acknowledgement ${ }^{3}$ through a number of factors:

1. The musicality of the theatrical event has in many cases gained a great deal of autonomy over previously central guarantors of sense, coherence and structure: the

\footnotetext{
${ }^{1}$ I would like to thank Nita Schechet and Jessica Berson for their patient advice and meticulous corrections. All remaining flaws, however, are mine.

2 'A good theatre production is like a good pop song'. www.wams.de/data/2003/08/10/149982.html, 27/09/2006.

3 See for example: Hans-Thies Lehmann, Postdramatic Theatre, (London \& New York: Routledge, 2006), pp. 91ff.; Erika Fischer-Lichte / Doris Kolesch / Matthias Warstat (eds.), Metzler Lexikon Theatertheorie (Stuttgart: Metzler, 2005) (entries 'Musik', 'Rhythmus'); Guido Hiß, 'Freiräume für die Phantasie! Neue Tendenzen in der Methodendiskussion', TheaterZeitSchrift, vol. 35/1993 Theaterwissenschaft morgen? pp. 19-29; David Roesner, Theater als Musik. Verfahren der Musikalisierung in chorischen Theaterformen bei Christoph Marthaler, Einar Schleef und Robert Wilson (Tübingen: Gunter Narr, 2003).
} 
dramatic text and the dramatic character. This does not mean that musicality and dramatic text and character are mutually exclusive but that musicality imprints itself with greater weight in the aesthetics, meaning-making and perception processes of a production.

2. In comparison to a more implicit, 'subcutaneous' musicality, that any form of theatre could rightfully claim, the past one or two decades have seen a shift towards a more explicit and self-reflexive use of music, musical parameters and forms. There has been a stronger emphasis on the musicality that is inherent in theatrical speech, movement, sound and structure. This shift manifests itself in the production processes of theatre as well as in the performances themselves and has therefore been seen as increasingly relevant for contemporary attempts on performance analysis.

3. The last several years have seen a variety of changes in the production habits and possibilities of theatre. New technological developments have given practitioners real-time control over many and various sound effects generated by the actor's voice; samplers and trigger-microphones and micro-ports have revolutionized the interplay between movement and stage, body and sound. And new artistic collaborations and interdisciplinary artistic self-images have been forged: it is very common for a German director nowadays to either to work continuously with the same theatre musician (Sebastian Nübling/Lars Wittershagen, Michael Thalheimer/Bert Wrede) or to be both director and musician/composer himself, in the manner of Goebbels, Marthaler, Pucher or Tsangaris.

In this article I would like to distinguish and exemplify a number of types of musicalization in contemporary German theatre, different levels of explicitness and various strategies of musicalization in the making of meaning and experience. I will look at the impact and the implications of musicalization on theatre on three not al- 
ways clearly separate levels: 1 . musicalization in the devising or rehearsal process; 2. musicalization as an organizational principle of performance and 3. musicalization and the perception process. I will argue that in 'Sprechttheater' (i.e. 'spoken theatre' as opposed to music-theatre, opera, ballet etc.) musicalization operates on these three levels. It shifts focus toward a different understanding of the creative processes of theatre, it sets a different performative register and an alternative structural coherence of the theatrical event and aims at different ways of engaging audience perception and reception. This approach is new, insofar as it reinvents and reassesses theatre from a musical perspective. It is also old, as there is a clear succession from the unity of song, dance and recitation in ancient Greek theatre, via the 'synesthetic visions'4 in pursuit of a theatrically total art work from early romanticism to Richard Wagner and beyond, via a variety of attempts in the historical avant-garde undertaken by Appia, Artaud, Craig, Meyerhold, Tairov and others, to contemporary theatre.

Musicalization takes theatre beyond the text as a primary guarantor of structure, narrative and sense and beyond the spoken word as the dominant materiality, but it cannot easily be set against text in a simple 'sense or sensuality' dualism. Musicality, I will argue, interacts in several diverse ways with the traditionally dominant elements of theatre: the character and its utterances. Musicalization can reassess and recontextualize the text, enhance our understanding of it, affirm and contradict it, simplify or obstruct our understanding and - one of many possibilities - replace it.

\section{II.1. Musicalization and Process}

Musicalization has become not only a striking feature of contemporary theatre performances in Germany, but is also often salient within the rehearsing and devising

\footnotetext{
4 Guido Hiß, Synthetische Visionen: Theater als Gesamtkunstwerk von 1800 bis 2000 (München: Epodium 2005).
} 
processes of both experimental and more traditional theatre productions. Practitioners may well start their process on the basis of a musical idea (Ruedi Häusermann's 'sound explorers' in Gewähltes Profil: Lautlos, Hannover, 2006), a musical setting (choirs on ships in the Stuttgart harbour in Tom Ryser's Singing River, Theater der Welt, 2005) or a musical piece (Prince's Joy of Repetition for Heiner Goebbels' Die Wiederholung, Frankfurt 1995), that then may be supplemented with text, in contrast to the more common theatrical practice of the other way round.

In Häusermann's Gewähltes Profil: Lautlos (profile: silent mode5), for example, the process of making, composing and rehearsing music for example became the central element of the production. Häusermann says:

Die Urzelle des Abends bilden meine Kompositonen für Streichquartett. Diese Musik ist die geistige Grundlage. Im Laufe des Abends kriegt sie eine Räumlichkeit. Sie wird sozusagen 'optisiert [...] Die Geschichten dieses Abends kommen aus der Musik heraus, werden sichtbar. ${ }^{6}$

The nucleus of this evening consists of my compositions for a string quartet. This music is the intellectual foundation. During the evening it achieves some spatiality. It becomes 'optified' [...] The stories of this evening emerge from the music, become visible. (my translation)

Häusermann characterizes the musical research he undertook with collaborators Martin Hägler and Martin Schütz, and a string quartet that he founded especially for the devising process of this piece, as a musical journey towards an ultimately theatrical event. The finally highly structured and minutely planned performance still represents the patient and open investigation into the unheard and the inaudible.

There is a scene in the first part of Gewähltes Profil for example, in which all the actors sit at individual desks and compose with string instruments, in a mixture of

\footnotetext{
5 The production uses the option menu 'silent mode' from mobile phones as its title.

6 Ruedi Häusermann, 'Dunkelschöpfung ins Licht gerückt.' Interview with Barbara Tacchini and Beret Evensen for the programme notes of Gewähltes Profil: lautlos. Staatstheater Hannover. Premiere on 6th May 2006, pp. 1-32 (p. 7f.).
} 
the artist's isolation and a music exam, while being watched by the actual string quartet. The scene is filled with the noises of eight performers coyly testing short notes on their instruments, putting down their bows, picking up pencils and writing their pieces of music. The act of composing - in this multiplied and abstracted form - becomes the music-theatrical event itself. In a later scene, 'Tonfischen' (fishing tones), a more absurd version of compositional self-reflexivity is presented: the music of a string quartet is 'fished' out of the air by other performers, who are equipped with taperecorders. They reassemble the sixteen partial recordings by mounting them on a stand, which Häusermann calls "Bienenstock" (Beehive). The individual voices of the string quartet are played back, but also altered by displacing them into a cluster: 'Bei der Wiedergabe gibt es kleine Verschiebungen, die Musik ballt sich in einer Klangwolke, die unscharf wird und sich verwandelt.7 ('During playback there are minor displacements, the music agglomorates into a cloud of sound, that becomes diffuse and transformed.') Häusermann and his collective's artistic processes of composing, collecting, and transforming are still characteristically present in the actual scenes, short-circuiting the music-theatrical process with the performance itself.

2. Musicalization plays an almost diametrically contrasting role in Sebastian Nübling's theatre productions. Nübling has worked with young people on adaptations of film scripts and novels, and has provided the state theatres of Munich, Hannover and Stuttgart with energetic, physically and rhythmically powerful stagings of classics from Shakespeare to Ibsen as well as contemporary plays by writers including Händl Klaus, Joanna Laurens or Tom Lanoye. While the music in his productions, always

\footnotetext{
7 Häusermann, 'Dunkelschöpfung ins Licht gerückt', p. 14.
} 
composed/adapted and often pre-recorded by Lars Wittershagen, usually serves as incidental music in an almost traditional way (i.e. structuring the scene, setting its pace or mood), there is a quite unique use of music in the rehearsal process.

After a first phase in which Nübling and Wittershagen decide on a specific musical cosmos that could connect with the play in question (e.g. music by Sarah Kane's favourite band Tindersticks for Nübling's production of Gier [Crave], Theater Basel, 2000), Wittershagen adapts, re-arranges and re-composes this music into different tracks and samples with a distinct atmospherical and rhythmical character. This material is played back often during the rehearsals, sometimes acting as a jump-start in eliciting a particular mood, sometimes as a friction that the actors have to go against and stand their ground. It also introduces an a new time order that dictates the pulse of the scene, and serves as a stage direction and tempo indication, on the basis of which Nübling develops the rhythmically precise and versatile physical interaction of his actors that has become his trademark. The playlist of songs or samples that Wittershagen assembles and modifies constantly on his computer serves as a dramaturgical, emotional and rhythmic backbone of the production. It becomes a kind of co-director in this process and an omnipresent additional collaborator on stage. In the end, while much of the music may not be played back anymore during the performances, it has become a kind of sub-text (or 'sub-music') that lives on in the minds of the actors as a shared internalized reference point. This use of music during the rehearsal process is at least partly responsible, I would argue, for the concentrated and precisely channelled performative energy of Nübling's productions. While in Häusermann's work the process and the patience of an almost excavating research is clearly visible and constitutes the performative result, Nübling uses the resistance of (popular) music and its almost uncontrollable richness in connotations prior to the performance as a re- 
hearsal technique that ultimately heightens the actors' awareness, presence and communication on stage.

\section{II.2. Musicalization and performance}

Musicalization has often been one of the means of achieving a certain liberation from logocentrism in the context of postdramatic theatre, but has also re-introduced the full range of textual potential: as a rhythmical, gesticulatory, melodic, spatial and sounding phenomenon as well as a carrier of meaning. Beyond that, musical characteristics of all elements of the theatrical event (for example the rhythmicality of the text, dynamic of movement, melodiousness of voice, tempo of succession of events, etc.) have been used on different levels (macro-/microstructure) as an organizational principle of performance.

I would like to expand and exemplify these observations now by looking at Christoph Marthaler's Murx (1993), the late Einar Schleef's groundbreaking production Ein Sportstück (1998) and, in most detail, Heiner Goebbels' Eraritjaritjaka (Lausanne 2004) ${ }^{8}$. I will choose a different focal point for each performance: musical form and structure for Marthaler, musical space for Schleef, and musical (re-) presentation for Goebbels.

Christoph Marthaler: the polyphonic 'flâneur'

Christoph Marthaler's projects and mise en scènes of existing dramatic works 9 very often follow a minutely and meticulously shaped succession of numbers: solos, ensembles, choirs, choreographies, that make ample use of repetition and variation.

\footnotetext{
8 Despite having been premiered at the Theatre Vidy, Lausanne (Switzerland) and being performed in French, Frankfurt-based Heiner Goebbels' work has been presented extensively in Frankfurt and Berlin, hence its inclusion here in the context of contemporary German theatre.

${ }^{9}$ For a list of his productions to date see: www.goethe.de/kue/the/reg/reg/mr/mar/ins/enindex.htm.
} 
Thus exhausting their informational, narrative or discursive potential quite quickly, the repetitions soon draw attention to the musical structure of the performance and allow for frequent re-assessments of the repeated performative elements. At the same time Marthaler's performances are truly polyphonic in the sense that several 'voices' (in this case: individual actor's performances) co-exist in a well-organized and yet independent and non-hierarchical simultaneity of events. Marthaler thus encourages the audience to become 'flâneurs' (strollers, idlers), visiting and re-visiting the same places and people, exchanging the same glances and remarks purposelessly.

In his most famous production 'Murx den Europäer' (Berlin 1993), which has been running at the Volksbühne for thirteen years now, Marthaler presents an ensemble of isolated, deranged, dysfunctional characters onstage, seated individually at scruffy tables ${ }^{10}$, caught in an inescapable sequence of events: telling dirty jokes, having tea, queuing for the bathroom, exercising physical violence, waiting. The precise attention Marthaler pays to the degree of repetition and variation, the alternation of phases of standstill and phases of agglomeration of events and the mesmerizing transition the actors frequently undergo from isolated, malevolent individuals to a beautifully and harmonically singing a-cappella ensemble utilize the duration and redundancy of 'Murx' to forge a greater musical structure. There is no dramatic progress, no narrative to speak of, no differentiated character psychology unfolding, but Marthaler creates a situation that allows for a heightened attention to the small, the banal, and the marginalized. Without ever mentioning politics, the GDR or German reunification, Murx paints a precise picture and serves as an echo chamber in which many of the unarticulated sentiments of its time reverberate.

10 See David Baltzer's photographs in Klaus Dermutz (ed.), Christoph Marthaler. Die einsamen Menschen sind die besonderen Menschen (Salzburg: Residenz, 2000), p. 63, 162, 173. 


\section{II.2.2. Schleef: Sportstück. The dynamic space}

Einar Schleef's first performance of Elfriede Jelinek's Ein Sportstück at the Wiener Burgtheater in 1998 was discussed widely in terms of its visual severity, its demanding duration (seven hours), its insistence and excessiveness. What was disregarded or highly simplified in those discussions was the production's abundant use of the musicality of voice, movement, space and light. Schleef has 'orchestrated' Jelinek's continuous text, which provides little or no dramatic information or characters, into a sequence of clearly separated rhythmitized tableaux. Every scene establishes a unique relationship between the approximately fifty-person choir and the few individualized protagonists, their spatial arrangement, the acoustic characteristics of their speech, and the rhythmical implications of the movements of their bodies and props (large balls mostly) in the highly geometric lighting system of the production.

Schleef composes extremes and contrasts; in one moment there are fifty people in white sportswear on the apron stage, facing the audience in an aggressive frontal posture, and shouting at the top of their lungs; at the next moment, you might find a solitary figure dressed in black reciting a fifteen-minute monologue with little dynamic development. Military barking is followed by chaste falsettos, movements of martial-arts regimes by anarchic and playful football kicking, song and dance by a five-minute full arrest of the production in meditative pose and silence.

Most notably and notoriously Schleef explores the rhythmical aspects of language, moulding language, pressing it into non-semantic meter, as well as liberating its expressiveness by multiplying its sound in many-voiced unison, compressing and decompressing on the level of a sentence or a syllable, and exposing it in a deliberately empty space. 
In Ein Sportstück he opened up the a vast stage space in the Burgtheater Wien right up its rear fire wall; in Verratenes Volk (Berlin 2000) he installed a huge white cyclorama that provided different reverberating types and times depending on the performers' position on the stage - a feature of which Schleef made extensive use by having groups of speakers and singers rotate around this acoustic setting on the revolving stage. 11 And in Wilder Sommer (Wien 1999), Schleef verticalized and multiplied the sound setup by putting the performers in a cut-open, three-storey house with a stairway in the middle and rooms at both sides, that served as six sound booths: disconnected from each other, while creating a wall of sound for the audience due to the often high-powered and simultaneous activities taking place within them.

The lighting system often adds to the musicality of the space. The sharp-edged horizontal stripes that layer the stage in many scenes of Ein Sportstück create rhythmic patterns of light and shadow on whoever walks through them: regular and measured on Bibiana Zeller, when she repeatedly walks straight from the back of the stage to the front: syncopated and fragmented on the forty-eight geometrically positioned performers of the longest movement choir of the production (because their martialarts based choreography with its kicks, steps and turns takes them constantly in and out of the light, with the occasional offbeat accent provided by forty-eight quickly lit elbows or feet 12 ) and finally providing quite an iridescent effects on the heads of the choir members as they traverse the full length of the stage in black cloaks.

Schleef uses simple props to create visual and spatial counter-rhythms. In Ein Sportstück he equips several scenes with white gymnastic balls that create a dense multi-metric visual and acoustic pattern during Bibiana Zeller's monologue, as they

\footnotetext{
11 See David Baltzer's series of photographs in Gabriele Gerecke / Harald Müller / Hans-Ulrich Müller-Schwefe (eds.), Einar Schleef. Arbeitsbuch (Berlin: Theater der Zeit, 2002), p. 45-48.

12 For a detailed musical analysis and notation of this scene see Roesner, Theater als Musik, pp. 193201 and the included CD-ROM.
} 
are rolled in various intensities and tempos from side to side within the lit vertical stripes. In another scene, actresses in rococo dresses recite their texts, half-singing, half-speaking in unusually high-pitched voices, while leisurely throwing the balls to each other. Again, the binary visual structure of the resting and flying balls and the sounds they create when caught, bring contrast and musical tension to the singsong of the recitation.

\section{II.2. Heiner Goebbels: Eraritjaritjaka. The double performer}

In addition to restructuring a performance's dramaturgy according to musical principles and redefining the theatrical space as a sonorous space, musicalization can have a major impact on the (re-)presentational qualities of an actor's or musician's performance in the theatrical environment. This is particularly evident in Heiner Goebbels' music theatrical productions. Not only does his cast usually reflect vastly variegated training and performing backgrounds (as classical musicians, jazz musicians, actors, dancers, performance artists, video artists, etc.), but he continually encourages them to do things on stage that they were not originally trained to do. ${ }^{13}$ André Wilms had to adjust his lines perfectly to a given piece of music (Eraritjaritjaka), trumpet player William Forman was asked to recite Edgar Allan Poe over his wireless trumpet microphone (Black on White), cameraman Bruno Deville had to time his movements and shot compositions to a tight musical score (Eraritjaritjaka), the musicians of the Ensemble Modern had to perform with tennis-balls, tea-kettles and brass instruments that most of them had to first learn to play (Black on White) etc.

\footnotetext{
13 See also Gerald Siegmund's characterization André Wilm's performance in Goebbels' Max Black (Lausanne 1998) in Gerald Siegmund, 'Task Performance als Choreographie. Die Aufgabe des Schauspielers', in Wolfgang Sandner (ed.), Heiner Goebbels. Komposition als Inszenierung (Berlin: Henschel, 2002), pp. 127-130.
} 
I trace two major tendencies and deliberate tensions in his approach to the actor's/musician's performance. The first track is informed by Goebbels' own interdisciplinary background and seeks the friction between the fascination of watching highly trained people doing what they are best at while concomitantly introducing elements, settings and tasks in which performers struggle and have to invest a new, intensified effort in order to achieve their performative assignments. The other tendency seems to be inspired by the essence of a musical score that conceptualizes and visualizes music as a multi-voiced texture of simultaneity and succession. In Heiner Goebbels' case, these voices are the different elements of theatrical performance, and it is characteristic of his compositional approach to think of a text, a movement, a sound or a light as distinguishable discrete elements of such a score that need not, and should not, simply duplicate each other. He says:

On stage I try to blur or even break the identity between speech and speaker in order to make the 'speaker' disappear. There are two reasons for this: first, to rescue the language, to develop the hearing of language independently, and second, to acquire an actor who can not only physically elaborate what he or she has already said but who can present himself or herself as an independent body - to arrive finally at having two bodies: the text as a body and the body of the actor. This can be achieved by using radio-mikes on stage, but also by strict stage directions such as: do not reiterate the movement of the text with body movements or with gestures of the hand, do not echo the contents with the enunciation by saying, for instance, 'bbbloodd' and 'sssworddd' instead of 'blood' and 'sword' to make it sound more violent. It is a common mistake amongst actors not to trust an understanding of words but to believe that through over-illustrating the sounds the narrative will be somewhat enriched. 14

And Cornelia Jentzsch adds and summarizes: 'Heiner Goebbels läßt in seinem Musiktheater sämtliche Komponenten - Text, Musik, Bild und Licht - versetzt

\footnotetext{
14 Heiner Goebbels, 'Text as Landscape. With the Qualities of Libretto, Even if Unsung'. Performance Research, 2/1997 Routledge.
} 
agieren, damit sich ihre unterschiedlichen Kräfte im Sinne des Stückes potenzieren'15. ('Heiner Goebbels staggers all the components of his music-theatre - text, music, image and light - so that their different strengths intensify each other in the spirit of the piece.' [my translation])

Looking at his latest production Eraritjaritjaka (2004) (which 'exhibits'16 writings by Elias Canetti and compositions for the string quartet, mostly from the $20^{\text {th }}$ century, performed by the actor André Wilms and the Mondrian Quartett), one can find that each of its sections renegotiates and redefines the relationship between different elements of the theatrical score and consequently the performative assignments for actor and musicians. The evening begins almost like a conventional concert: the Mondriaan Quartett are seated conventionally and play the first two movements of Shostakovich's Eighth String Quartet. Singled out by particularly focussed lighting and, unusual for classical concerts, amplified by microphones, their performance is somewhat visually and aurally intensified, but it is still primarily the performance of a string quartet.

Soon this musical 'monologue' becomes a dialogue: the short rhythmic phrases of Alexeij Mossolov's String Quartet no. 1, op. 24 find themselves complemented, answered or provoked by André Wilms'/Canetti's brief interjections. On top of that, Goebbels then adds a third rhythmic layer: the measured movements of a beam of light that follows (or guides?) the actor's movements like an inverted shadow. Interestingly, every added 'voice' questions the interdependence of the music, the actor and the stage anew. When Wilms intersperses his comments in the musical score, it soon seems uncertain, whether the music comments on the words or vice versa. Similarly, it is undecided whether the beam of light follows or directs the actor's movements. At

\footnotetext{
15 Cornelia Jentzsch, 'Die Songline in Canettis Denken'. www.heinergoebbels.com, accessed on 26 October 2006.

16 Its subtitle is 'museé des phrases'.
} 
any rate the specific interplay of all these elements seeks to avoid any kind of illustration: it is an extension of Goethe's characterization of Beethoven's string quartets: 'als ob sich vier vernünftige Menschen miteinander unterhalten'17. It is an extension because a beam of light, a remote-controlled 'scanner', or a cameraman, can become the fifth, sixth, seventh member of this quartet; an extension because their 'conversation' is not necessarily stringent or closed or followed by some kind of conclusion.

When half an hour later André Wilms leaves the theatre followed by cameraman Bruno Deville, and his taxi journey through the respective city in which Eraritjaritjaka is performed that night is being projected on the façade of a large white house on stage18, Gavin Bryars' String Quartet No. 1 seems to function primarily as film music. There is a slight twist in this particular 'film music' as both the film and the film score are produced live - the musicians play live on stage and the video feed of Wilms' journey is initiated in front of the audience and never visibly interrupted or cut. 19.

Heiner Goebbels also provides a second hint that the audience shouldn't take for granted the seemingly conventional relationship between music, stage, and acting that the intimated genre affiliation seems to conjure: He does this by projecting onto the aforementioned façade, which has four black double windows, and by placing the quartet's cellist in front of the bottom right corner of this façade 20 ; as the windows cut holes into the projected image, one is constantly reminded of the gaps in this cinematic experience, and as the audience's gaze darts from the magnified face of André

\footnotetext{
17 'As if four sensible people are having a conversation with each other' (my translation).

18 See photographs of the production by Mario Del Curto and Klaus Gruenberg on www.heinergoebbels.com/.

19 We learn only later in the performance that the taxi-journey - despite its efforts to come across as a live-feed - must have been produced prior to the performance.

20 Although there is no photograph of this particular scene on www.heinergoebbels.com, the existing photographs of the production by Mario Del Curto and Klaus Gruenberg make it easy to visualize what I am describing here.
} 
Wilms to the dwarfed cellist (who becomes part of the projection as well as part of the perforated screen) and back, the distribution of roles (on screen/off screen, actor/musician, live/mediated) is once again questioned.

This state of negotiability of the actor's and musicians' tasks and affiliations is reinforced in other moments of the performance: When the Mondriaan Quartett perform Vassily Lobanov's String Quartet No. 4 three of them are lined up standing in front of the white floor-cloth facing the audience, and their cellist sits behind the cloth some fifteen feet away. And when they perform the fourth movement, Vif et agité, of Ravel's String Quartet in F, they have joined André Wilms in the interior of the filmed apartment and sit leisurely on the living room couch - in both instances the sheer deviation from convention, the obviously increased difficulty in executing the musical score, the visible inclusion of the musicians within the theatrical space heighten the physical presence of the musicians, fictionalize their interaction and make them 'acting musicians'.

André Wilms, on the other hand, frequently transforms into a 'musician-actor'; whether it is his chopping of onions that sets the pace for the second movement of Ravel's quartet, Assez vif-Très rythmé, or whether his recitation of the serial poetry that Goebbels has collocated from different Canetti sources, each sentence beginning with 'Là-bas' (down there) becomes the fifth voice in Bach's Contrapunctus 9 from the Art of Fugue. In the latter example, Goebbels puts Canetti's disapproving aphorism 'In music, instead of walking, as they normally do, words swim'21 to the test. The finding is that the way Goebbels composes the interplay between text and music the words, movements, lights and actions don't swim, but flee - in the original meaning of the word 'fugue': flight (from lat. 'fuga'). They flee being attached to a single mean-

\footnotetext{
${ }^{21}$ Elias Canetti in: Heiner Goebbels, Eraritjaritjaka. Musée des Phrases. Based on texts of Elias Ca-
} netti. English Textbook (2004). 
ing, genre, acting style, or possible interpretation, escaping their media boundaries and becoming intermedial phenomena.

Musicalization serves here not merely as a means of introducing a structural order, but as a means 'against interpretation', against spoon-feeding the audience a particular view, a particular understanding. It liberates the different elements of theatrical communication, by allowing them to adopt and adapt music's potential for counterpoint and polyphony. It allows for dialogues and polyphonic conversation between the voices of theatre that reach beyond the text, not by dismissing or subordinating it, but by releasing it into a playful multiplicity of conjunctions and confrontations.

\section{II.3. Musicalization and Sense(s)}

Politik des Theaters ist Wahrnehmungspolitik. [...] Sein [des Theaters, DR] politischer Einsatz liegt nicht in den Themen, sondern in den Wahrnehmungsformen. (original italics) 22

'The politics of theatre is a politics of perception. [...] Its engagement does not consist in the topics but in the forms of perception. (trans. by Karen Jürs-Munby)

It is one thing to concede, identify and differentiate forms and levels of musicalization in contemporary theatre but quite another to ask about the implications of this particular aspect of theatrical practice. ${ }^{23}$ Not intending to provide an exhaustive list of aesthetic, psychological, political, or other consequences of musicalization for the perception process, I would like to point out a few examples that have proved particularly significant or common amongst the practices that I associate with musicalization

\footnotetext{
22 Hans-Thies Lehmann, Postdramatisches Theater (Frankfurt am Main: Verlag der Autoren, 1999), p. 469.

23 Although this essay focuses on musicalization in relation to the audience, it is not my intention to claim or provide evidence for 'objective' audience reactions or perceptions; instead I refer to plausible implications and strategies of musicalization and, occasionally, explicitly expressed intentions of its practitioners.
} 
in contemporary German theatre. I center them around three key aspects: hierarchy, duration, and expectation/coherence.

\section{Hierarchy}

In many of the practices I have mentioned, musicalization re-negotiates the interdependence of the theatrical means of expression involved as well as the relationship between the 'internal and external communications' system'24. Christoph Marthaler and Heiner Goebbels in particular make use of the idea and characteristics of musical polyphony - the independence and autonomy of each contributing voice in a piece written for several voices, as opposed to homophony, where all voices are subordinated rhythmically and harmonically to a single lead voice. They extend and apply this idea to the theatre as a whole: In Marthaler's theatre this is particularly salient in the musical and a textual material he collocates as well as in the organization of his 'chorischen Ensembles'25 (chorus ensemble) in the space and time of the performance. The different materials and eclectic sources of his devised projects as well as the personnel on stage are used polyphonically in the sense, that maintain their autonomy and individual specific weight, but at the same time form a perfectly attuned collective. This allows the individual audience member to let his/her attention oscillate between being absorbed by minute detail (like Bruno Cathomas' drooling in Murx (Berlin 1993) and watching with what Anton Ehrenzweig calls 'dedifferentiation'26 - a kind of unconscious scanning (for instance in order to capture the spatially and temporally wide-spread rhythm of the collapsing beds in Stunde Null, Hamburg 1995).

\footnotetext{
24 Manfred Pfister, The Theory and Analysis of Drama, (Cambridge; Cambridge University Press, 1991), p 40.

25 Detlev Baur, 'Der Chor auf der Bühne des 20. Jahrhunderts', in Riemer, Peter / Zimmermann, Bernhard (eds.) Der Chor im antiken und modernen Drama (Stuttgart: Metzler, 1999), pp. 227-246, (p. 227).

26 Anton Ehrenzweig, The Hidden Order of Art: a Study in the Psychology of Artistic Imagination (London: Weidenfeld \& Nicolson, 1967), p. 123.
} 
Heiner Goebbels takes this idea even further by extending the musical process of de-hierarchization to virtually all constituent elements of the theatre, including lighting, sound design and video. He also reflects this approach more explicitly as the attempt to elicit critical awareness, maturity, and self-determination in the audience. The strategies of de-hierarchization, to which Goebbels is committed in his collaborative devising processes as well as in treatment of his material(s) are intended to spill over to the reception process:

Alle Hierarchisierung [...] ist ihrem Wesen nach totalitär, so auch in der Kunst. Das Totalitäre macht im Theater auch nicht vor den Zuschauern Halt. Es springt frontal von der Rampe herunter, um das Publikum zu überwältigen, zu bevormunden. [...] Für eine eigene Erfahrung bleibt kein Raum. 27

All hierarchization [...] is in its essence totalitarian, art being no exception. The totalitarian in theatre doesn't stop at the audience. It frontally jumps down from the apron stage in order to overwhelm the audience, to patronize it. [...] There is no room for an individual experience. (my translation)

Goebbels argues against dissolution of the individual arts and 'voices' in a total work of art aesthetics, and for a kind of interplay that allows them to assert themselves in 'einem kontinuierlichen Schwebezustand gehaltenen Präsenz'28 ('a presence that is held in a constant state of suspense'). This, according to Goebbels, then allows for a theatre of experience, the 'success' of which is the shared responsibility of artists and audience.

The idea of the musical score and the principles of polyphony allow Marthaler, Goebbels and others to offer their theatrical material in new ways that are less logocentric or character-driven. Another very common strategy in the attempt to 'take

\footnotetext{
27 Heiner Goebbels, 'Gegen das Gesamtkunstwerk. Zur Differenz der Künste', in Wolfgang Sandner (ed.) Heiner Goebbels. Komposition als Inszenierung (Berlin: Henschel 2002), pp. 135-141 (p. 135). 28 Goebbels, 'Gegen das Gesamtkunstwerk', p. 136.
} 
aback and widen the perception'29 is the musical approach to duration. Directors like Marthaler and Schleef (and René Pollesch, Frank Castorf, Michael Thalheimer etc.) introduce elements of repetition, extreme tempos (retardation/acceleration) or explicit rhythmicality into their work beyond a narrative or character-based motivation or justification.

\section{Duration}

Klaus Dermutz' monograph on Christoph Marthaler bears the title: 'Die langsamen Menschen sind die besonderen Menschen' ('Slow people are special people'). I would argue that a political or moral attribution given a certain tempo - as in this title - is by no means coincidental. Marthaler's work has repeatedly employed slowness as an aesthetic feature as well as a reflection of a conscious resistance to a society where speed and acceleration have become major aims and achievements. In an interview ${ }^{30}$ he said, he observed that more and more people seem to be pushed aside by the centrifugal powers of our time and so fall off the fast-spinning carrousel, and that it was precisely these people he took an interest in watching, studying, and putting on stage as characters in his theatrical inventions.

Marthaler's choice of tempo and his refusal to develop theatrical situations in a conventional narrative way create a sense of exposure. The audience feels exposed to a different experience of time, but at the same time the theatre reveals itself as a kind of slow motion replay to its audience who are thus granted time to listen, watch and study in detail.

\footnotetext{
29 '... die Wahrnehmung zu frappieren und zu erweitern', theatre-musician Ulrike Hage in Ralph Hammerthaler / Elisabeth Schweeger (eds.), Räumungen (Berlin: Alexander Verlag, 1999), p. 104.

30 Renate Härtl, 'Verweile doch, du bis so schön. Christoph Marthaler inszeniert Goethes Faust 1+2'. TV-Documentation by Renate Härtl (director) and Werner Czarnojon, Michael Neuenhagen (camera) for ZDF, 1994
} 
Einar Schleef, on the other hand, who has rarely produced a piece of theatre lasting less than five hours, uses duration in a more painfully transformative way. Where Marthaler's audiences are invited to explore the virtues of his 'discovery of slowness' (Sten Nadolny) from the perspective of a flâneur, Schleef overwhelms his audiences by blasting conventions and expectations of time and creates an often productive irritation with the theatrical event itself. His production Salome (Düsseldorf 1997) opened with a long silent tableau:

Die vordere Wand gleitet auf und zeigt den gesamten nackten Bühnenraum, 40 Meter tief, kein Gegenstand, nur der schmale Steg bis zum Ende, geschnitten von dem Rampensteg, also ein bombastisches Kreuz. Um den Steg herum stehen Männer, einzeln, in schwarzen Frauenkleidern, unbewegt im blauen Licht, nur vorn wohl eine Frau, hockend, unter einem orientalischen Tuch. Stille. Drei Minuten. Fünf Minuten. Räuspern im Publikum, Husten. Acht Minuten. Klatschen, Rufen, gehässiges Lachen, schließlich 15 Minuten dieses schweigende Totenbild gegen den Unmut des Publikums. Vereinzeltes Schauspielerkollektiv gegen geballtes, gesittet aufmuckendes Zuschauerkollektiv. Aber je lauter das Publikum wird, desto stärker, unberührter, selbstgenügsamer wird das Bild. ${ }^{31}$

The front wall slides open and shows the entire naked stage space, forty meters deep, not a single object, just the thin catwalk right to the end cuts across at the front of the stage - a gigantic cross. Around the catwalk there are men, isolated, in women's black clothing, immobile in blue light, and just in front a woman, squatting under an oriental piece of cloth. Silence. Three minutes. Five minutes. Clearing of throats in the audience, coughing. Eight minutes. Applause, yelling, spiteful laughter, finally fifteen minutes of this silent image of death against the audience's displeasure. And isolated in an ensemble of actors versus a concerted civilizedrebellious audience collective. But the noisier the audience gets, the stronger, more unmoved, self-sufficient the image becomes. (my translation)

Marthaler and Schleef reinstate theatre as a real-time medium and resist other media's tendencies to highly elliptic narratives. 32 But they also reinstate timing and rhythm as autonomous, self-sufficient, non representational factors of theatre, just like

\footnotetext{
31 Andreas Schäfer, 'Im Untergehen scheint die gute Seite auf - Einar Schleef inszeniert in Düsseldorf Wildes Salome', Berliner Zeitung (23 June 1997).

32 Most narrative music video-clips exemplify this, as does any contemporary cinema thriller.
} 
Michael Thalheimer or René Pollesch do on the faster end of the scale. In the rhythmical over- or undercoding that these techniques of musicalization result in there is also a fundamental critique of the teleology and causality that are suggested in most areas of life. The football playing boys in Schleef's Ein Sportstück, for example, who play for almost eight minutes with no detectable relevance, aim or intended pun or the 'laughing old man' that appears in several of Marthaler's productions and takes ages to set up a few microphones both irritate our habitual expectations about narrative or performative efficiency. In a theatre where repetition, pauses, silence, lack of focus, multiple characters and a circular sense of time predominate, the audience finds itself confronted with fragmentation, contingency and a necessity to endure that probably corresponds more aptly to their individual experiences of daily life than does the latest well-made play or telenovella. A seemingly abstract use of musical principles thus transforms into a highly accurate reflection and questioning of the concrete ways we experience our environment. In this sense, musicalization is brought into play in contemporary German theatre as a means of thematizing audiences' expectations and their co-production of coherence by dissociating both from their traditional 'provider': the dramatic text.

\section{Expectation / Coherence}

As music is an abstract, mostly non-referential 'language', it is to be expected that musicalization in theatre will also result in changes in the audience's traditional expectations of theatrical communication. When Marthaler abandons structuringsystems like narrative, story or character development in his devised productions ${ }^{33}$ and replaces them with a dramaturgy of (musical) numbers or 'acts', the audience is

\footnotetext{
33 For example: Murx (Berlin, 1993), Stunde Null (Hamburg 1995), The Unanswered Question (Basel
} 1997), Die Spezialisten (Hamburg 1999), 20th Century Blues (Basel 2000), or O.T. (Zurich 2004). 
encouraged to ask different 'why?' and 'what was that for?' questions than those they are used to. The necessity for a certain scene or action may well be predominantly musical and a concern about its psychological motivation would be misleading for both the performers and the audience.

At the same time, theatre is never as purely abstract and self-referential as music can be. And convention will always make us approach a theatre space with a different set of expectations of causality, coherence and narrativity than those with which we approach a concert hall. Musicalization on the theatrical stage questions and plays with those expectations, offering new cohesive strategies and elements: the investigation of voices, the musical development of a visual or acoustic motif, the experience of time, or the sonority of space, for example. At first sight, the inclination of a theatrical event towards the self-referentiality and self-reflexivity of music is a liberation of the semiotic compulsion: the obligation to see (what the Prague School addressed as) the primarily semiotic function of everything on stage. And potentially, by worrying less about 'what it means', the audience can focus their attention on 'what it is' and thus challenge, widen and reflect on their own modes of perception and observation. At the same time, musicalization in the theatre will always deal with concrete spaces, bodies, texts and para-texts that almost inevitably make it into a kind of 'programme music'34. Meaning and coherence can thus be reintroduced though the back door by making use of the connotative referential potential of music.

Let me give two more examples: In Marthaler's Stunde Null (Zero Hour), a production based on the difficulties of commemorating the fiftieth anniversary of the end of WWII, Graham F. Valentine launches into a long speech, that is collocated from

\footnotetext{
34 Here the theatre situation provides what Liszt, who introduced the term programme music, characterized as a 'preface added to a piece of instrumental music, by means of which the composer intends to guard the listener against a wrong poetical interpretation, and to direct his attention to the poetical idea of the whole or to a particular part of it.' (Cit. in Roger Scruton, 'Programme music', Grove Music Online, ed. L. Macy, http://www.grovemusic.com, accessed 14 May 2007.
} 
decrees of the Allies in English, French, Russian and German and sound poetry by Kurt Schwitters. As his speech becomes more and more nonsensical, turning towards gibberish and pure vocal sound, it actually makes more and more 'sense', shifting from bureaucratic jargon, meaningless in its edited form, to a vocal evocation of the war's soundscape (through the syllables of Kurt Schwitters: trucks, machine-guns, bombs, crackling radio reception, etc.), which becomes easily comprehensible as an eerie echo with a fifty-year delay. 35

In Einar Schleef's Verratenes Volk the rhythmitized choral delivery of passages from Alfred Döblin's novel November 1918 makes it deliberately difficult to follow the text in a discursive way. However, the friction between the revolutionary impetus of the choir (the military tone of multiplied and rhythmically organized voices) and its rhythmic shape (the increasing rhythmical stumbling, the often counter-semantic phrasing, the uneven metric accentuation) 'makes' the audience read the text against the grain and 'tells' us that the ostentatious self-confidence of the revolutionary masses is in fact quite questionable. 36

\section{Conclusion}

Musicalization, it appears, is more than merely a new fashion on the German stage, more than just a different 'wrapping', more than old wine in new barrels. It profoundly changes ways and techniques of theatrical production, introducing new dramaturgies and structure to the theatrical performance and challenging the expectations and meaning-making processes of the audience.

In short, musicalization may modify existing forms of theatrical fabric or even invent new ones. However, the implications of this have not yet been fully absorbed

\footnotetext{
35 For a more detailed analysis of this scene see Roesner, Theater als Musik, pp. 80-9.

36 For a more detailed analysis of this scene see Roesner, Theater als Musik, pp. 215-6.
} 
in the organisational structures of theatre training, theatre production, theatre criticism and theatre studies - musicalization necessitates interdisciplinarity on all these levels. It requires actors and directors that are trained for a sense of rhythm, sound and musical structure; it asks for theatres that render the rigid boundaries between the separated 'Sparten' (fields; usually: theatre, opera, ballet) porous; it asks for journalists who are competent to review productions that fall between conventional genres; and it needs new approaches in the academy to reassess the questions and methods at hand with respect to their suitability in analyzing the aesthetic processes, performances and perceptions of the intermedial, intermodal and interdisciplinary phenomena that musicalization in German theatre continues to generate. 